\title{
Intussusception of the small intestine - a rare cause of gastrointestinal obstruction in adults - case report
}

\author{
Wgłobienie jelita cienkiego - rzadka przyczyna niedrożności przewodu pokarmowego \\ u dorostych - opis przypadku
}

\author{
Marzena Lenda-Petrykowska ${ }^{\bowtie}$, Szymon Kositowicz
}

Pomorski Uniwersytet Medyczny w Szczecinie, Oddział VIII Chirurgii Ogólnej i Naczyniowej, SPWSZ Szczecin-Zdunowo, ul. Sokołowskiego 11, 70-880 Szczecin Pomeranian Medical University of Szczecin, VIII Department of General and Vascular Surgery in Szczecin, SPWSZ Szczecin-Zdunowo

$\triangle$ maszajn@gmail.com

\begin{abstract}
Intestinal intussusception is most common in children. In adults, it is a relatively rare disorder. It usually occurs with a noticeable triggering factor: a lead point (LP).

The following is the case of a 36-year-old man admitted to the Department of General Surgery SPWSZ in Szczecin-Zdunowo
\end{abstract}

\section{ABSTRAKT}

Wgłobienie jelita najczęściej występuje u dzieci. U dorosłych jest stosunkowo rzadkim schorzeniem. Przebiega zwykle z uchwytnym czynnikiem wywołującym, tzw. lead point (LP), punktem prowadzącym, czołem wgłobienia.

\section{CASE REPORT}

A 36-year-old man reported to the hospital emergency department (SOR) due to persistent intense abdominal pain lasting several days, abnormal vomiting, and constipation of gas and stools. The patient reported a periodic occurrence of similar complaints in the past, which subsided spontaneously. So far, he had not been treated chronically and had not been operated on. Physical examination revealed bloated stomach with marked peritoneal symptoms and muscular defense, palpable resistance in the middle intra-abdomen, and emptiness in the right iliac quadrant, with a rectal mucocutaneous-dark bloody discharge. In additional studies: features of inflammation (leucocytosis 12.9 thousand/L), hyponatremia ( $133 \mathrm{mmol} / \mathrm{L}$ ). In the performed CT, intussusception was confirmed (Fig. 1 and 2). Due to the symptoms and their duration, physical examination, and the results of additional tests, the patient was qualified for urgent laparotomy.

The abdominal cavity was opened from a midline incision surrounding the navel. The distended loops of the small intestine were visible along the entire length. In the peritoneal cavity, there was a significant amount of straw-colored liquid - bacteriological samples were collected; the rest was removed. The due to pain in the abdomen caused by intussusception of the small intestine.

Keywords: intussusception; forehead of intussusceptum; lead point; acute abdomen syndrome; obstruction of the gastrointestinal tract.
Poniżej przedstawiono przypadek 36-letniego mężczyzny przyjętego na Oddział VIII Chirurgii Ogólnej SPWSZ w Szczecinie-Zdunowie z powodu dolegliwości bólowych jamy brzusznej, wywołanych wgłobieniem jelita cienkiego.

Słowa kluczowe: wgłobienie; czoło wgłobienia; punkt prowadzący; ostry brzuch; niedrożność przewodu pokarmowego. intussusception of the small intestine, through Bauhin's valve to the cecum and the ascending colon, was exposed (Fig. 3). The cecum and part of the ascending colon were significantly distended with a parchment-like wall on the border of the perforation (Fig. 4). The gastrointestinal tract was retrogradely decompressed through a nasogastric tube, obtaining $800 \mathrm{~mL}$ of congestive fecal content. After the maneuver the operating space was increased. Multiple attempts to mobilize the intussusception were unsuccessful. Therefore, the decision was made to resect part of the ascending colon, the cecum with the intussusception, and a portion of the necrotic ileum behind the intussusception. The hepatic flexure of the colon was mobilized. An ileocecal anastomosis was performed laterally with an $80 \mathrm{~mm}$ mechanical linear stapler and additionally hand-sutured. The mesentery of the intestine was sutured. After rinsing the peritoneal cavity with Betadine solution and physiological saline, achieving thorough hemostasis, and inserting Redon's drain, the abdominal wall was closed. The resected intestine was sent for histopathological examination.

Postoperatively, the specimen was dissected, removing the small intestine from the cecum and part of the ascending colon, only after cutting the ileocecal valve and cecal wall (Fig. 5 and 6). At a distance of approximately $50 \mathrm{~cm}$ from Bauhin's 


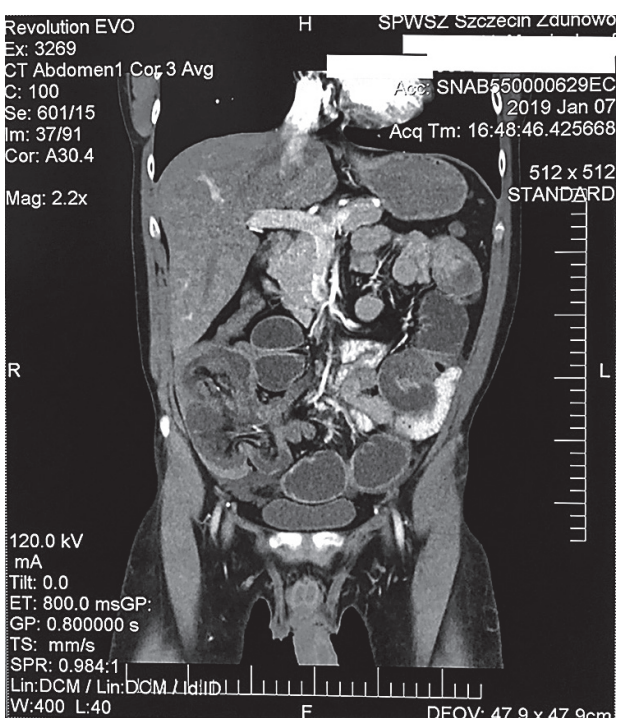

FIGURE 1. A computed tomography image of the intussusception

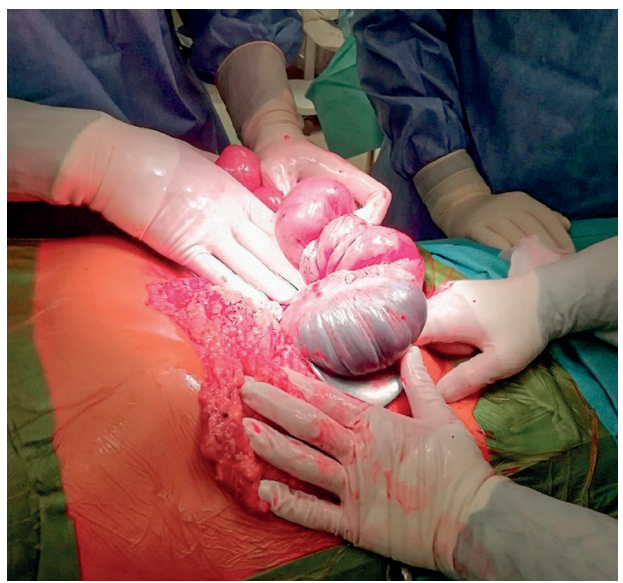

FIGURE 3. An intraoperative photo of the intussusception

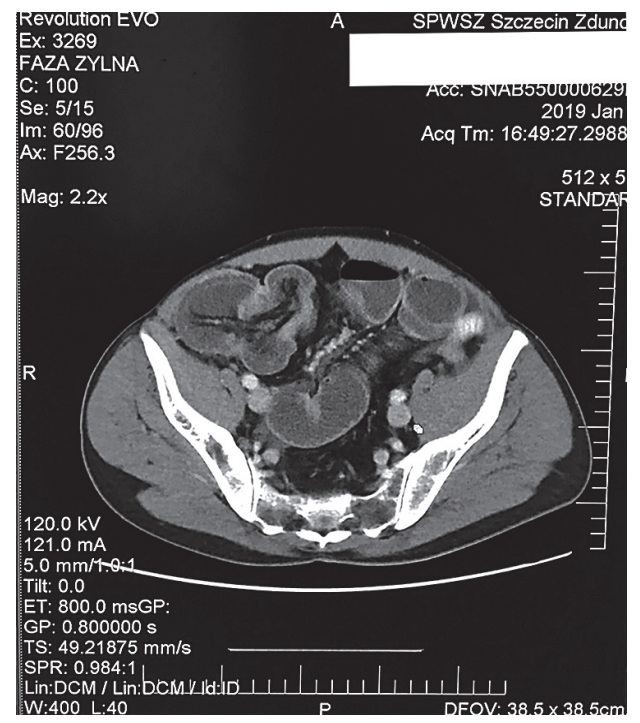

FIGURE 2. A computed tomography image of the intussusception II

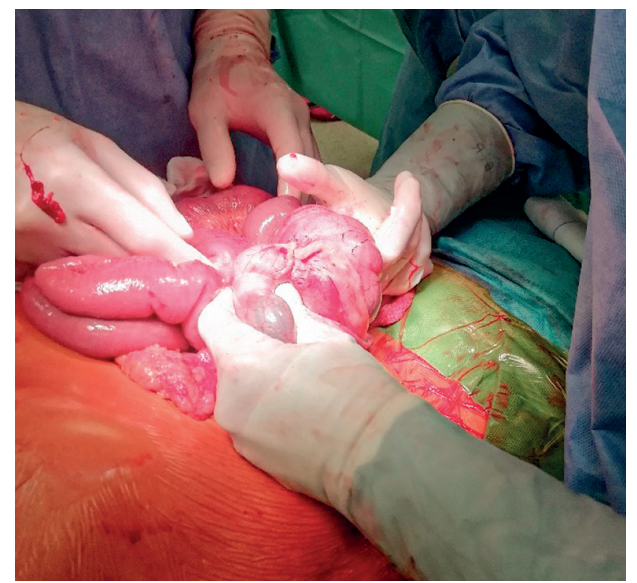

FIGURE 4. Intraoperative picture II

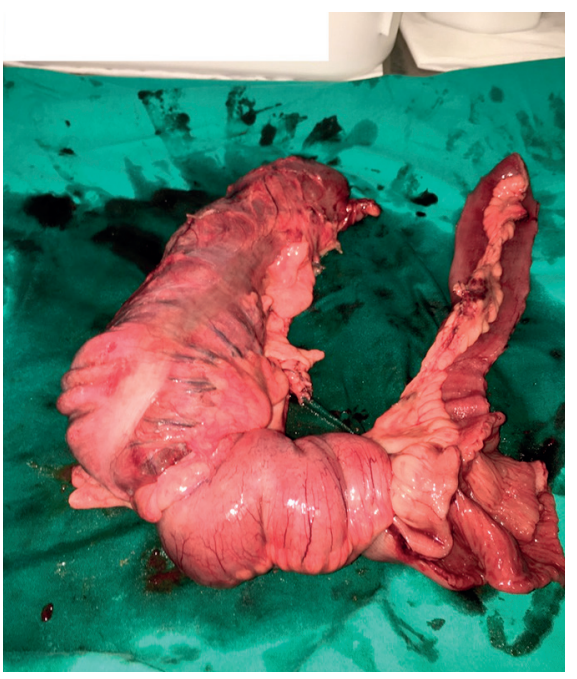

FIGURE 5. Postoperative preparation - part of the ascending colon, cecum, intussusception, part of the ileum

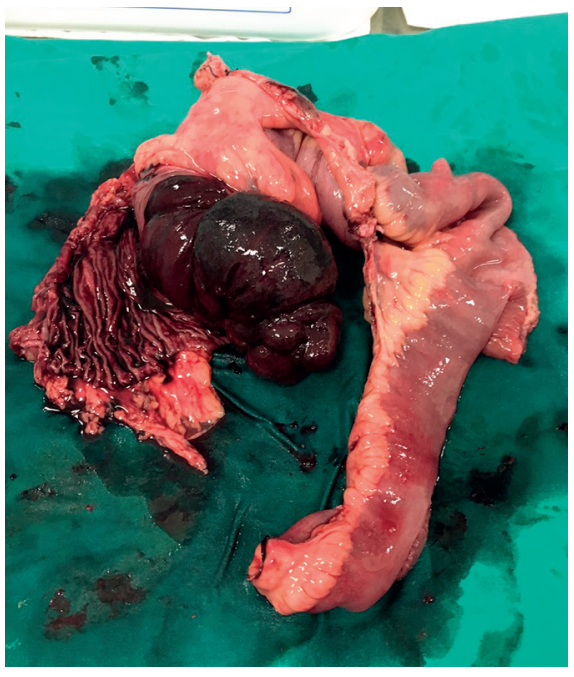

FIGURE 6. Postoperative material

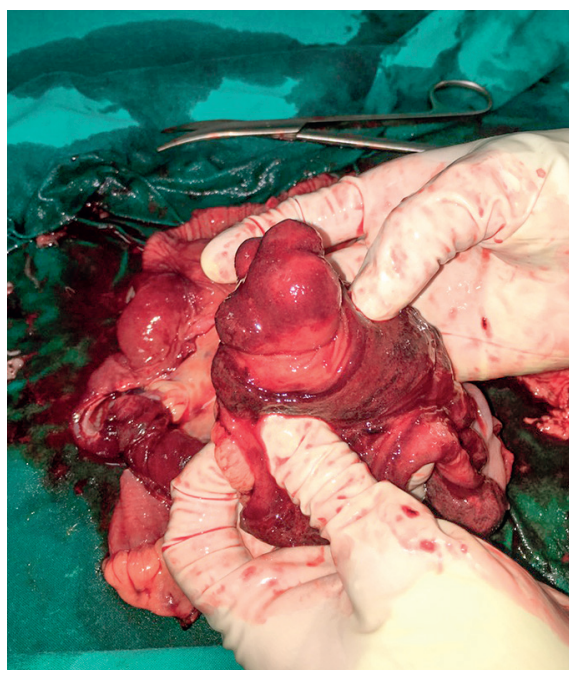

FIGURE 7. Postoperative material intussusception 
valve, a tumor growing into the intestinal lumen on a broad base of $4 \times 5 \mathrm{~cm}$ (Fig. 7) was visualized. The result of histopathological examination - lipoma submucosum (submucosal lipoma).

In the postoperative period, the patient continued antibiotic therapy, physical and respiratory rehabilitation, and gradual broadening of the diet. The patient was discharged in a good general condition on the $7^{\text {th }}$ postoperative day.

\section{DISCUSSION}

Intestinal intussusception in adults is rare. It is mainly a childhood condition (majority of cases under the age of 2). A significant number of cases in juvenile patients occur without any diagnosed cause - idiopathic form. In adults, the cause is usually known; there is often a lead point (LP) of the intussusception [1]. It may be a small intestine polyp, a tumor: a submucosal lipoma, mucous cyst (mucocele), overly long stump after appendectomy, postoperative suture line, or Meckel's diverticulum, but also cystic fibrosis, Crohn's disease, posttraumatic hematoma, or trichobezoar $[1,2,3]$.

The most common types of intussusception are ileocecal jejuno-jejunal, and colono-colonic [2]. Characteristic symptoms are (according to the literature) colic abdominal pain, vomiting, palpable tumor in the abdomen, as well as rectal secretion of currant/raspberry discharge (late symptom). The characteristic radiological feature, on the other hand, is the image of the target sign [1].

In children, there is the possibility of attempting conservative treatment: rectal insufflation with air, application of saline under appropriate pressure or barium under X-ray control $[1,4]$.

In adults, $90 \%$ of cases are diagnosed with LP $[1,2]$. Often the symptoms are recurrent and subside spontaneously. For this reason, patients often do not report to the doctor and delay treatment.

\section{CONCLUSIONS}

Despite the development of imaging diagnostics, intussusception remains a disorder requiring surgical intervention in adults. The surgical procedure, as (usually) the only form of treatment, is often associated with segmental resection of the lesion and the intussuscepted intestine [5]. The main aim is to dissect, and in cases of segmental necrosis - to resect, the smallest possible fragment of the intestine - conditioned by morphological changes found intraoperatively - and to perform enteric-intestinal anastomosis or, if it is impossible, to create a temporary/permanent stoma. Subsequent treatment and prognosis depend on diagnosis based on the histopathological result of the lesion causing the intussusception.

\section{REFERENCES}

1. Szmidt J. Podstawy chirurgii. T 2. Kraków: Medycyna Praktyczna; 2004. p. 468-70.

2. Nielubowicz J. Ostre schorzenia jamy brzusznej. Warszawa: PZWL; 1958. p. 271-94.

3. Bolívar-Rodríguez MA, Fierro-López R, Pamanes-Lozano A, CazarezAguilar MA, Osuna-Wong BA, Ortiz-Bojórquez JC. Surgical outcome of jejunum-jejunum intussusception secondary to Rapunzel syndrome: a case report. J Med Case Rep 2018;12(1):362.

4. Maślanka M, Górniak K, Prokurat A. Wgłobienie jelitowe - diagnostyka i leczenie. Klinika Chirurgii Dziecięcej, Uniwersytet Jagielloński Collegium Medium, Polsko-Amerykański Instytut Pediatrii. Pediatr Dypl 2012;16(4):36-40.

5. Zollinger RM Jr, Zollinger RM Sr. Atlas zabiegów chirurgicznych. Wrocław: Elsevier; 2007. p. 114-5. 